\title{
The Effect of Accelerators and Mix Constituents on the High Early Strength Concrete Properties
}

\author{
V. M. Sounthararajan and A. Sivakumar \\ Structural Engineering Division, VIT University, Vellore 632014, India \\ Correspondence should be addressed to A. Sivakumar, sivakumara@vit.ac.in \\ Received 24 February 2012; Accepted 15 May 2012 \\ Academic Editor: M. Maslehuddin
}

Copyright ( 2012 V. M. Sounthararajan and A. Sivakumar. This is an open access article distributed under the Creative Commons Attribution License, which permits unrestricted use, distribution, and reproduction in any medium, provided the original work is properly cited.

The present research study focused on the high early strength concrete properties that can be produced with large replacement of cement by fly ash. Also, the effects of adding fibres on the compressive strength gain and early age strength gain properties are determined. Tests were conducted on different high strength concrete specimens, where fly ash was substituted for cement up to $50 \%$. Different types of concrete specimens were casted and tested for different fine-to-coarse aggregate ratio, metallic fibre content, cement-to-total-aggregate ratio, and accelerator dosage. The test results indicated that high early strength concrete $(50.7 \mathrm{MPa}$ at 7 days) was obtained for higher F/C ratio of $0.8, \mathrm{C} / \mathrm{TA}$ ratio of 0.24 , and higher dosage level of steel fibre at $1.5 \%$.

\section{Introduction}

High-early-strength-based cementitious materials are of vital importance for the present expanding civil infrastructure. However, the deterioration of civil infrastructure all over the world has led to the realization that cementitious materials must be improved in terms of their engineering property and durability. The use of admixtures such as fly ash has little effect on pozzolanic properties to improve the engineering properties of fly-ash-substituted concrete. In a structural concrete durability should be high, as presented by waterto-binder ratio (W/B). A concrete structure is said to be durable if it withstands the conditions for which it has been designed, without deterioration for the entire period of life [1-5]. However, use of chlorides may cause corrosion in steel reinforcing and is prohibited in some countries, so that calcium nitrates can be potentially used to achieve high early strength concrete. These techniques are especially useful in the prefabrication industry, wherein high early age strength enables the removal of the formwork within 24 hours, thereby reducing the cycle time, resulting in cost-saving benefits [6]. Pozzolana increases the later age strength of concrete as it reacts with calcium hydroxide and turns it into calcium-silicate-hydrates (C-S-H). However, Portland pozzolana cements have higher activation energy and, therefore, their rate of hydration is lower as compared to ordinary Portland cements [7]. In a similar context, the addition of steel fibers improves the concrete matrix in all mechanical properties of concrete such as compressive strength, spilt tensile strength, flexural strength, and toughness. Steel-fiber-reinforced concrete is made for cement-based composite material reinforced with randomly distributed steel fibers diameter. It contains pozzolans and admixtures commonly used in pavement construction in civil works [8]. In this similar area of research, it can be observed from earlier studies that the durability properties of concrete is not affected in the case of high early age strength gain in concrete [9]. Also, the addition of mineral and chemical admixtures contributed towards the increase in the rate of strength gain and showed an improvement in the 1 day compressive strength upto $30 \mathrm{MPa}$ which can be sufficient for early removal of formwork $[10,11]$. It can be noted that both compressive strength and UPV of all the samples increased especially for samples containing fly ash. The relationship between UPV and compressive strength was found to be exponential for mineral admixtures [12]. The nondestructive testing using ultrasonic testing technique was further extended to study the steel-fiber-reinforced cementitious materials to predict the influence of volume fraction and fibre geometry on the engineering properties 
TABLE 1: Mixture proportions of various concrete mixes.

\begin{tabular}{|c|c|c|c|c|c|c|c|c|c|c|}
\hline Mix Id & $\mathrm{W} / \mathrm{C}$ ratio & $\mathrm{F} / \mathrm{C}$ ratio & $\mathrm{C} / \mathrm{TA}$ ratio & Flyash \% & Fibres \% & Accelerator & $\begin{array}{l}\text { Cement } \\
\mathrm{Kg} / \mathrm{m}^{3}\end{array}$ & $\begin{array}{c}\text { Fine aggregate } \\
\mathrm{Kg} / \mathrm{m}^{3}\end{array}$ & $\begin{array}{c}\text { Coarse aggregate } \\
\mathrm{Kg} / \mathrm{m}^{3}\end{array}$ & $\begin{array}{l}\text { water } \\
\mathrm{Kg} / \mathrm{m}^{3}\end{array}$ \\
\hline M1A1 & 0.3 & 0.6 & 0.26 & 25 & 0.5 & 1 & 473 & 672 & 1113 & 142 \\
\hline M1A2 & 0.3 & 0.6 & 0.26 & 50 & 0.5 & 1 & 473 & 672 & 1113 & 142 \\
\hline M1A3 & 0.3 & 0.6 & 0.26 & 25 & 1.5 & 1 & 473 & 672 & 1113 & 142 \\
\hline M1A4 & 0.3 & 0.6 & 0.26 & 50 & 1.5 & 1 & 473 & 672 & 1113 & 142 \\
\hline M2B1 & 0.3 & 0.8 & 0.24 & 25 & 0.5 & 1 & 433 & 815 & 1019 & 130 \\
\hline M2B2 & 0.3 & 0.8 & 0.24 & 50 & 0.5 & 1 & 433 & 815 & 1019 & 130 \\
\hline M2B3 & 0.3 & 0.8 & 0.24 & 25 & 1.5 & 1 & 433 & 815 & 1019 & 130 \\
\hline M2B4 & 0.3 & 0.8 & 0.24 & 50 & 1.5 & 1 & 433 & 815 & 1019 & 130 \\
\hline M3C1 & 0.4 & 0.6 & 0.26 & 25 & 0.5 & 1 & 473 & 672 & 1113 & 142 \\
\hline M3C2 & 0.4 & 0.6 & 0.26 & 50 & 0.5 & 1 & 473 & 672 & 1113 & 142 \\
\hline M3C3 & 0.4 & 0.6 & 0.26 & 25 & 1.5 & 1 & 473 & 672 & 1113 & 142 \\
\hline M3C4 & 0.4 & 0.6 & 0.26 & 50 & 1.5 & 1 & 473 & 672 & 1113 & 142 \\
\hline M4D1 & 0.4 & 0.8 & 0.24 & 25 & 0.5 & 1 & 433 & 815 & 1019 & 130 \\
\hline M4D2 & 0.4 & 0.8 & 0.24 & 50 & 0.5 & 1 & 433 & 815 & 1019 & 130 \\
\hline M4D3 & 0.4 & 0.8 & 0.24 & 25 & 1.5 & 1 & 433 & 815 & 1019 & 130 \\
\hline M4D4 & 0.4 & 0.8 & 0.24 & 50 & 1.5 & 1 & 433 & 815 & 1019 & 130 \\
\hline
\end{tabular}

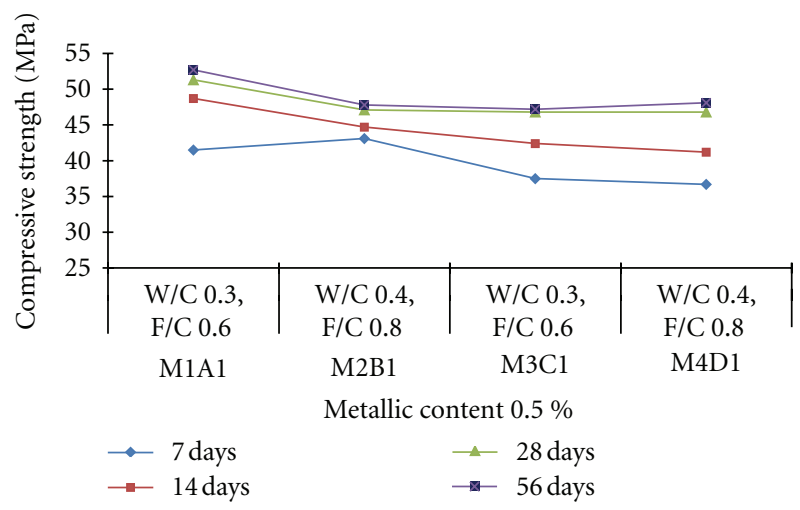

Figure 1: Compressive strength of concrete at $25 \%$ fly ash for different mixture proportions.

of concrete. The present study is aimed at exploring the strength characteristics of cementitious system, containing steel fibers, fly ash, and accelerator at different dosages. Also, the rate of hardening was monitored using a portable ultrasonic pulse velocity tester.

\section{Materials and Experimental Methods}

Ordinary Portland cement of 53 grade having 28-day compressive strength of $54.9 \mathrm{MPa}$, satisfying the requirements of IS: $12269-1987$ was used. The specific gravity of cement was found to be 3.12. Fine aggregates obtained from locally available river sand passing through $4.75 \mathrm{~mm}$ IS sieve conforming to grading zone II of IS: 383-1978 was used. It has fineness modulus of 2.60, a specific gravity of 2.69 , and water absorption of $0.97 \%$ at 24 hours. Coarse aggregates of crushed blue granite stone with $12.5 \mathrm{~mm}$ maximum size conforming to IS: $383-1978$ was used. The

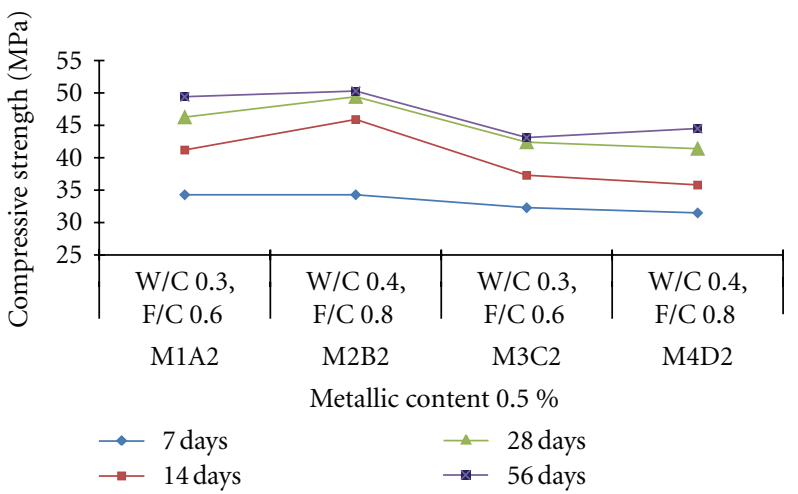

Figure 2: Compressive strength of concrete at 50\% fly ash for different mixture proportions.

specific gravity was found to be 2.75 , fineness modulus 6.5 , and water absorption $0.62 \%$ at 24 hours. A sulphonated naphthalene formaldehyde based superpalsticizer was used in the study which conforms to ASTM type F and IS: 91031999. Specific gravity of SNF was 1.20. Fibers conforming to ASTM A820-01 were used, end hooked steel fibers were used at dosage levels of 0.5 and $1.5 \%$ by volume fraction of concrete, the diameter of steel fibres was $0.5 \mathrm{~mm}$, length was $30 \mathrm{~mm}$ and its aspect ratio $(1 / \mathrm{d})$ of 60 , ultimate tensile strength was $900 \mathrm{MPa}$, and elastic modulus was $210 \mathrm{GPa}$. An accelerator was used to obtain a high early strength concrete at dosage level of $1 \%$ by weight of cement. The concrete mixture proportions used in the study are provided in Table 1. The total 16 different concrete mixtures were proportioned based on the cement-to-total-aggregate ratio (C/TA) 0.24 and 0.26, water-to-cement ratio (W/C) 0.3 and 0.4 , and fine-to-coarse-aggregate ratio $(\mathrm{F} / \mathrm{C}) \quad 0.6$ and 0.8 . The concrete mixtures were mixed using a 40 -liter container 


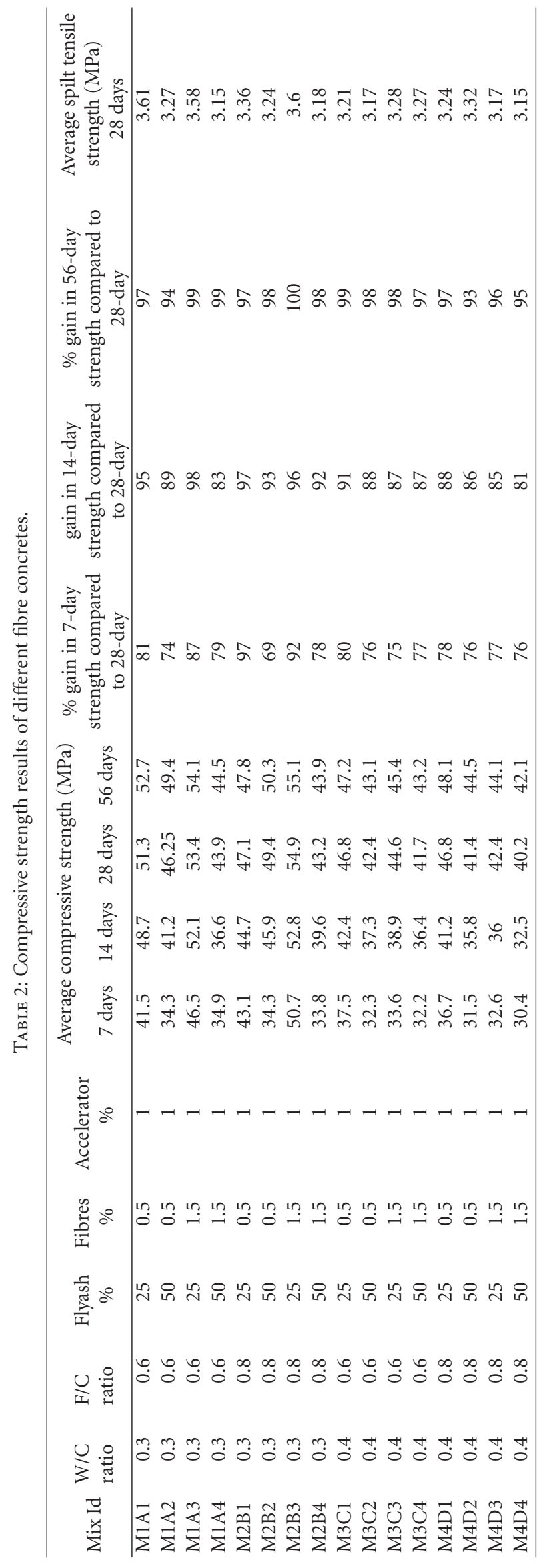




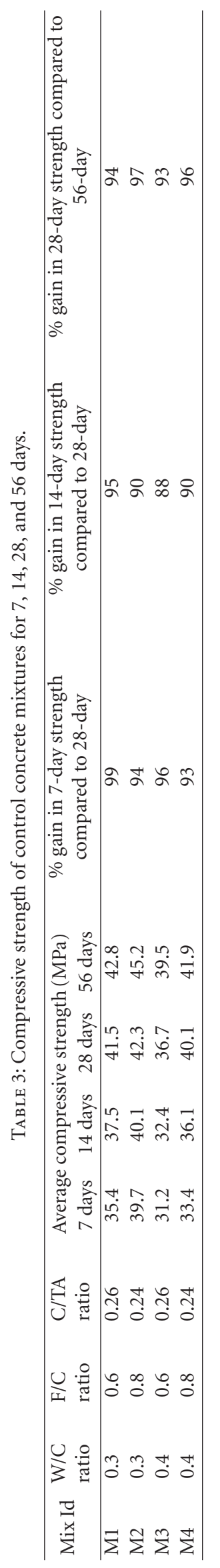




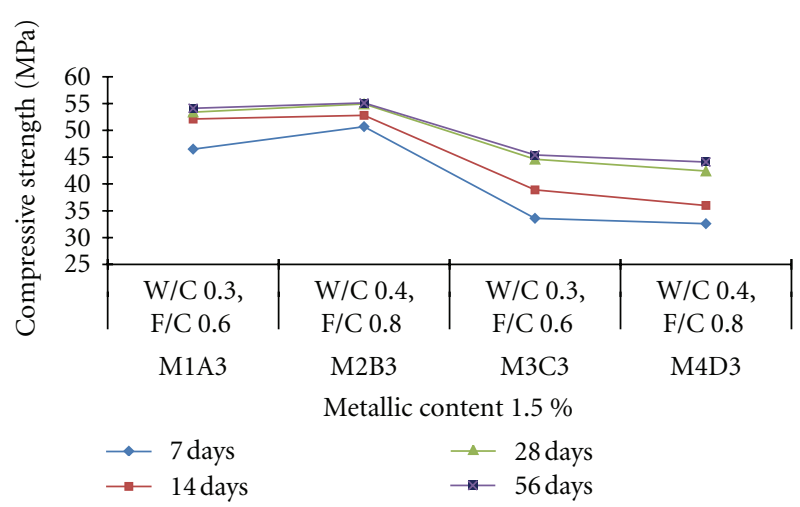

Figure 3: Compressive strength of concrete at 25\% fly ash for different mixture proportions.

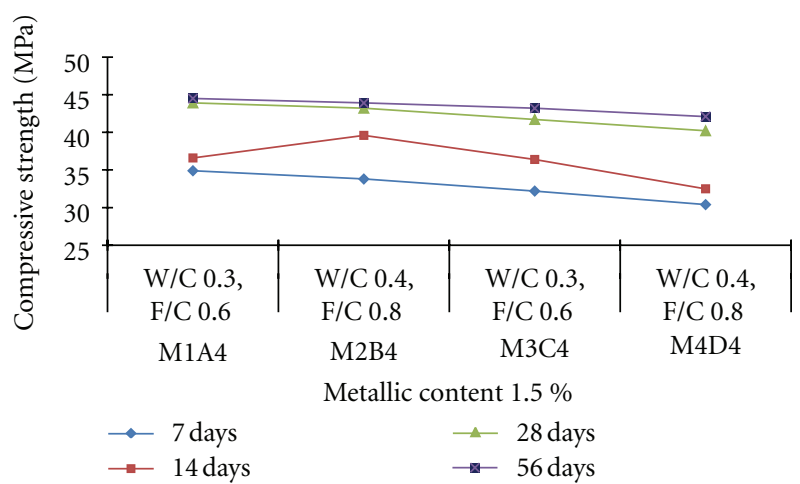

Figure 4: Compressive strength of concrete at 50\% fly ash for different mixture proportions.

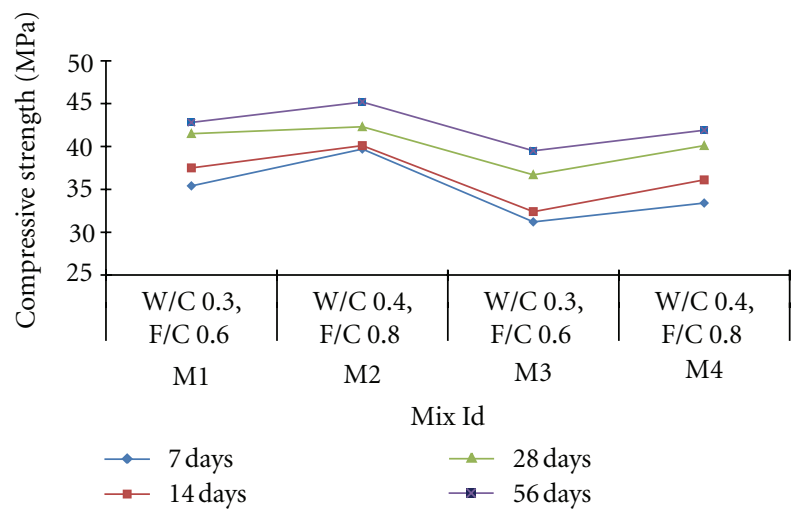

FIgURE 5: Compressive strength for different mix proportions of controlled concretes.

with tilting drum type mixer, and specimens were cast using steel mould, the standard cube $(100 \times 100 \times 100 \mathrm{~mm})$ moulds, and cylinders ( $100 \mathrm{~mm}$ diameter $\times 200 \mathrm{~mm}$ height $)$ and compacted with table vibrator. For each mix at least three specimens were remoulded 24 hours after casting and water-cured at $27 \pm 2^{\circ} \mathrm{C}$ until the age of testing of $1,3,7$, 14,28 , and 56 days. All the specimens were cured in the same curing tank to maintain uniform curing for all the specimens.

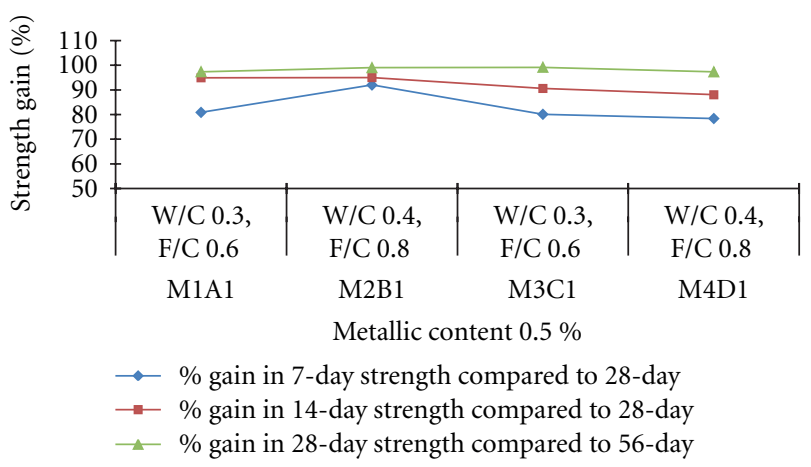

Figure 6: Percentage strength gain at 25\% fly ash for different mixture proportions.

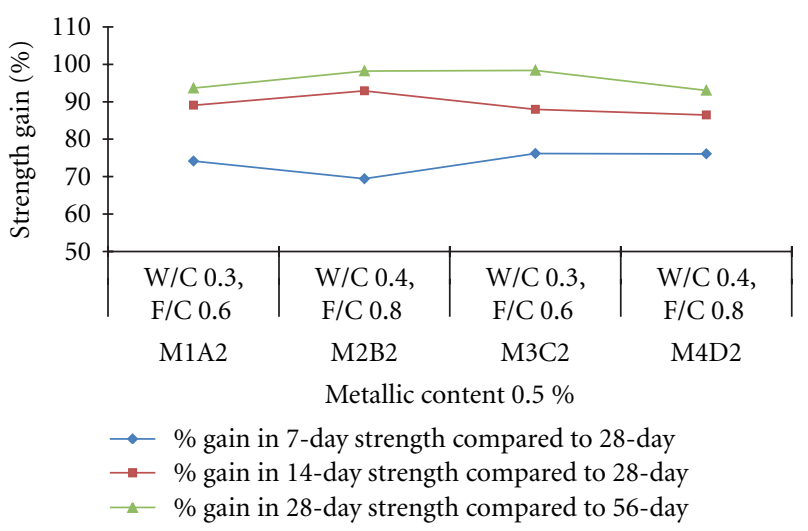

Figure 7: Percentage strength gain at 50\% fly ash for different mixture proportions.

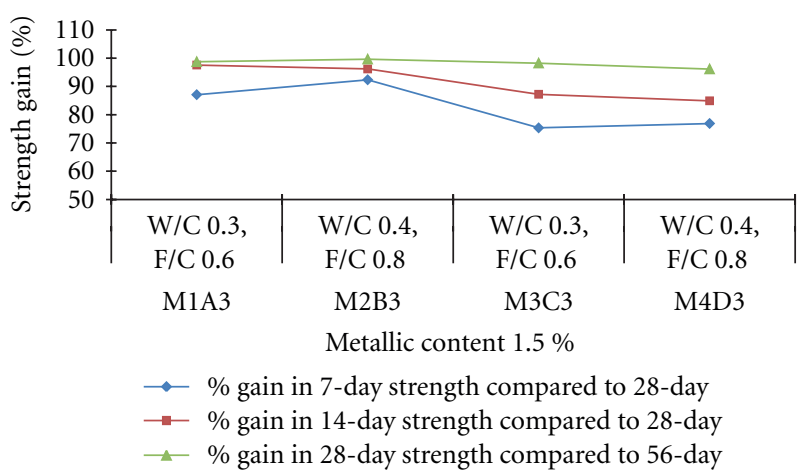

FIGURE 8: Percentage strength gain at $25 \%$ fly ash for different mixture proportions.

\section{Experimental Test Results and Discussions}

The compressive test results of different concrete mixtures are given in Tables 2 and 3 and shown in Figures 1, 2, 3,4 , and 5. It can be observed that compared to control concrete all the concrete composites containing metallic fibre content showed higher strength. It can also be noted that the variables such as cement-to-aggregate-ratio and fine to coarse-aggregate-ratio affected the compressive properties greatly when the W/C ratio was 0.3 as observed in Figure 1. 


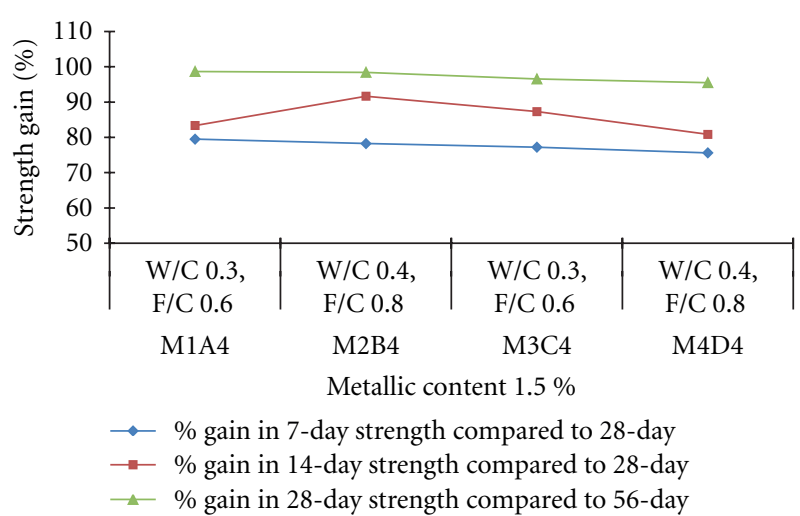

Figure 9: Percentage strength gain at 50\% fly ash for different mixture proportions.

Similarly it can be seen from Figures 2 and 5, that compared to $0.3 \mathrm{~W} / \mathrm{C}$ ratio, $0.4 \mathrm{~W} / \mathrm{C}$ showed higher strength due to higher F/C (0.8) ratio, whereas the C/TA (0.24) was lower than the lower W/C (0.3) ratio. Also, the same trend was observed for the controlled concrete mix, which resulted in marginal increase in the compressive strength for W/C and C/TA ratio. Also it is well noted that higher F/C ratio used in concrete resulted in higher strength. This can be justified based on the fact that both the parameters C/TA and $\mathrm{F} / \mathrm{C}$ ratio have significant effect on the improvement the rate of strength gain (as observed in Figures 6, 7, 8, and 9). This can lead to delayed cracking in concrete upon loading. The split tensile properties further showed similar trend as that of compressive strength. The test results on the early age hardening in few hours after demoulding the concrete specimens were recorded and are shown in Table 4. The ultrasonic test results values showed that the strength gain after 1 day exhibited a good increase in pulse velocity and satisfied the IS 13311 (shown in Figure 10). This essentially shows that the good quality concrete was obtained at much earlier period of curing with the addition of accelerator and fibres.

\section{Conclusions}

Based on the above experimental investigation, the following conclusions can be drawn.

(i) The use of class F flyash and accelerator showed that early age setting properties of concrete can be more useful where high early fast track concreting is required. Also, the addition of metallic content has significant effect on the compressive and split tensile properties of concrete.

(ii) The careful selection of different variables such as cement-to-aggregate-ratio and fine to coarseaggregate-ratio has significant effect as well as cement-to-aggregate-ratio which provided greater improvements in the mechanical properties of concrete.

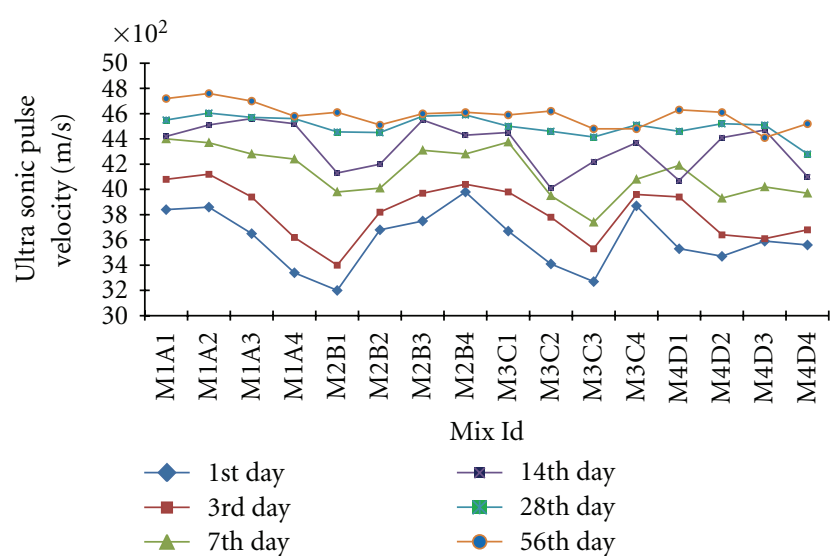

FIGURE 10: Ultrasonic pulse velocity for different mixture proportions of concrete.

TABle 4: Ultrasonic pulse velocity $(\mathrm{m} / \mathrm{sec})$ measurements for various concretes.

\begin{tabular}{lcccccc}
\hline \multirow{2}{*}{ Mix Id } & \multicolumn{5}{c}{ Curing days } \\
& 1st day & 3rd day & 7th day & $\begin{array}{c}\text { 14th } \\
\text { day }\end{array}$ & $\begin{array}{c}\text { 28th } \\
\text { day }\end{array}$ & $\begin{array}{c}56 \text { th } \\
\text { day }\end{array}$ \\
\hline M1A1 & 3840 & 4080 & 4400 & 4420 & 4550 & 4720 \\
M1A2 & 3860 & 4120 & 4370 & 4510 & 4605 & 4760 \\
M1A3 & 3650 & 3940 & 4280 & 4560 & 4570 & 4700 \\
M1A4 & 3340 & 3620 & 4240 & 4520 & 4560 & 4580 \\
M2B1 & 3200 & 3400 & 3980 & 4130 & 4455 & 4610 \\
M2B2 & 3680 & 3820 & 4010 & 4200 & 4450 & 4510 \\
M2B3 & 3750 & 3970 & 4310 & 4550 & 4580 & 4600 \\
M2B4 & 3980 & 4040 & 4280 & 4430 & 4590 & 4610 \\
M3C1 & 3670 & 3980 & 4375 & 4450 & 4500 & 4590 \\
M3C2 & 3410 & 3780 & 3950 & 4010 & 4460 & 4620 \\
M3C3 & 3270 & 3530 & 3740 & 4220 & 4415 & 4480 \\
M3C4 & 3870 & 3960 & 4080 & 4370 & 4510 & 4480 \\
M4D1 & 3530 & 3940 & 4190 & 4070 & 4460 & 4630 \\
M4D2 & 3470 & 3640 & 3930 & 4410 & 4520 & 4610 \\
M4D3 & 3590 & 3610 & 4020 & 4470 & 4510 & 4410 \\
M4D4 & 3560 & 3680 & 3970 & 4100 & 4280 & 4520 \\
\hline
\end{tabular}

(iii) It is clearly evident that early strength gain in concrete is a function of low water-cement-ratio, F/C ratio, accelerator dosage, and cement-to-totalaggregate ratio. Cement replacement up to $50 \%$ fly ash showed early age strength gain slightly lower than concrete made with $25 \%$ fly ash. Therefore, concrete mixes containing class $\mathrm{F}$ ash can be used up to $50 \%$ safely to produce high early strength concrete for precast products.

(iv) It was observed from the test results that the higher strength was obtained for $\mathrm{W} / \mathrm{C}$ ratio $0.3, \mathrm{~F} / \mathrm{C}$ ratio 0.8 , and C/TA ratio 0.24 with metallic content $1.5 \%$ from which the compressive strength at 28 days was 54.9 $\mathrm{MPa}$ and a similar trend was noted for lower $\mathrm{W} / \mathrm{C}$ ratio of $0.3, \mathrm{~F} / \mathrm{C}$ ratio 0.6 , and $\mathrm{C} / \mathrm{TA}$ ratio 0.26 
with higher metallic content $1.5 \%$ from which the test result value for 28 days was $53.4 \mathrm{MPa}$. It can be concluded that higher fine-to-coarse-aggregates ratio and metallic fiber content up to $1.5 \%$ showed higher strength. The addition of accelerator has direct effect on the early strength gain and resulted in attaining the 28 days in a short duration of 7 days.

\section{References}

[1] T. R. Naik and B. W. Ramme, "Low cement content high strength concrete," Cement and Concrete Research, vol. 17, no. 2, pp. 283-294, 1987.

[2] K. Ganesh Babu and G. Siva Nageswara Rao, "Efficiency of fly ash in concrete with age," Cement and Concrete Research, vol. 26, no. 3, pp. 465-474, 1996.

[3] BIS (Bureau of Indian Standards), "Specification for 53grade Ordinary Portland cement,” IS 12269-1987, New Delhi, India, 1987.

[4] BIS (Bureau of Indian Standards), "Non-destructive testing of concrete Part 1 Ultrasonic pulse velocity," IS 13311-1992, New Delhi, India, 1992.

[5] ACI Committee 544, "Guide for specifying, mixing, placing and finishing steel fiber reinforced concrete," ACI 544. 3R- 95, American Concrete Institute, Detroit, Mich, USA, 2006.

[6] P. S. Song and S. Hwang, "Mechanical properties of highstrength steel fiber-reinforced concrete," Construction and Building Materials, vol. 18, no. 9, pp. 669-673, 2004.

[7] S. R. Parimi and J. K. S. Rao, "Effectiveness of random fibres in fibre-reinforced concrete mechanical behaviour of materials," in Proceeding International Conference on Mechanical Behaviour of Materials, vol. 5, pp. 176-186, 1971.

[8] P. Rossi, "Mechanical behaviour of metal-fibre reinforced concretes," Cement and Concrete Composites, vol. 14, no. 1, pp. 3-16, 1992.

[9] A. E. Naaman and H. Hammoud, "Fatigue characteristics of high performance fiber-reinforced concrete," Cement and Concrete Composites, vol. 20, no. 5, pp. 353-363, 1998.

[10] C. Huang and G. Zhao, "Properties of steel fibre reinforced concrete containing larger coarse aggregate," Cement and Concrete Composites, vol. 17, no. 3, pp. 199-206, 1995.

[11] S. M. Mohammed and B. Mohamed, "Properties of concrete reinforced with different kinds of industrial waste fibre materials," Construction and Building Materials, vol. 23, no. 10, pp. 3196-3205, 2009.

[12] J. H. Bungey, "The validity of ultrasonic pulse velocity testing of in-place concrete for strength," NDT International, vol. 13, no. 6, pp. 296-300, 1980. 

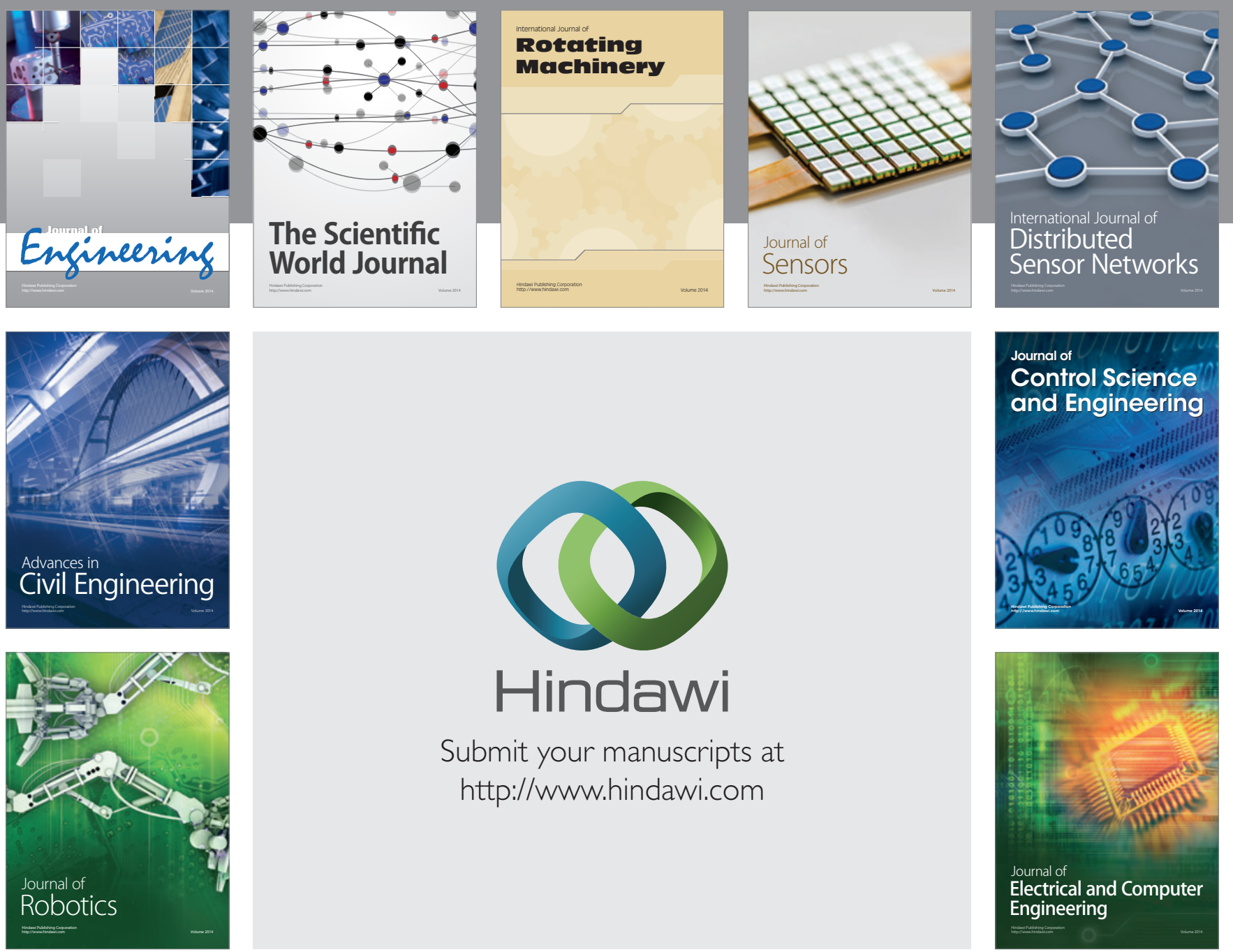

Submit your manuscripts at

http://www.hindawi.com
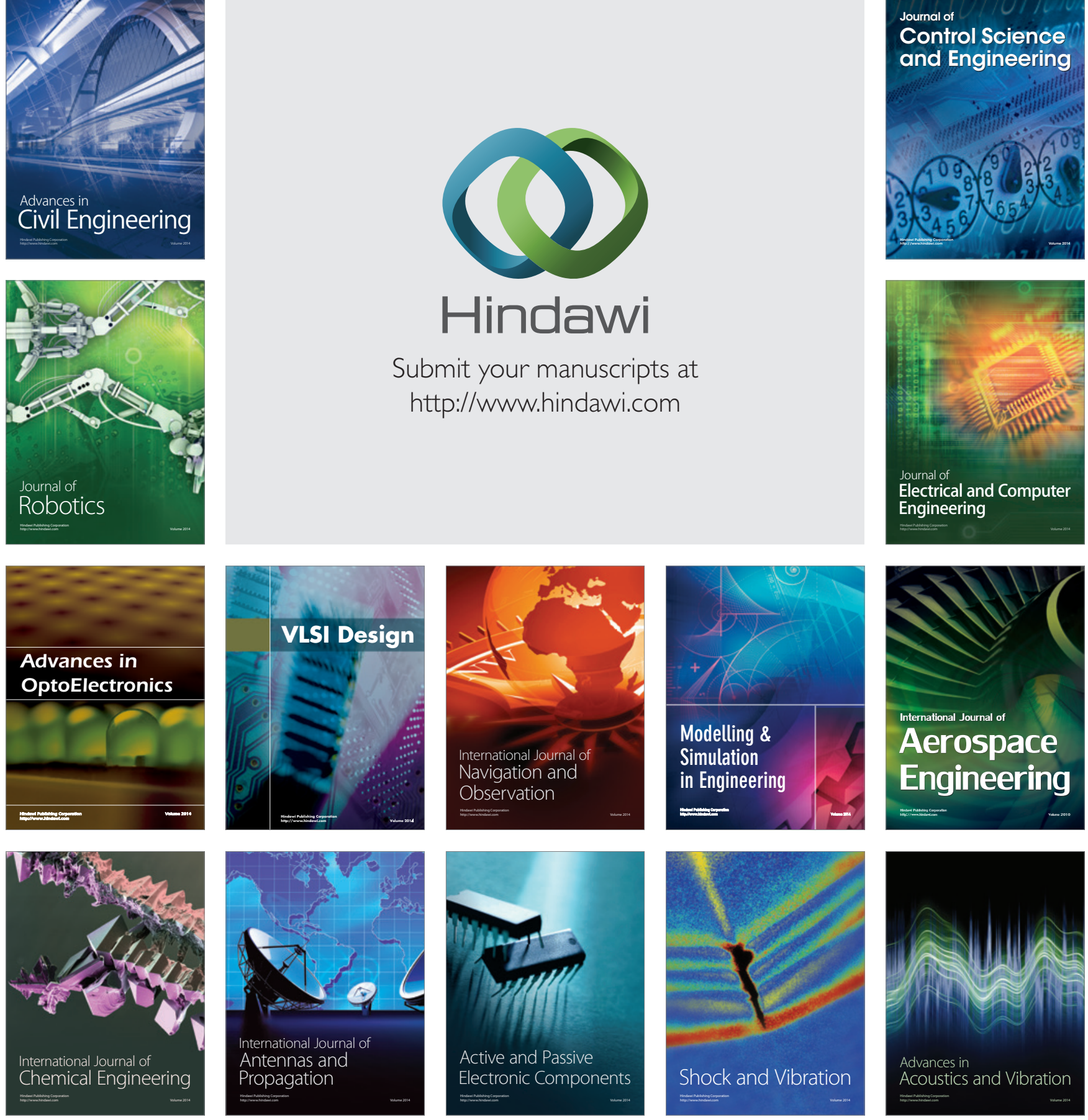